Pesq. Vet. Bras. 30(10):877-880, outubro 2010

\title{
Evaluation of a recombinant p24 antigen for the detection of Feline Immunodeficiency Virus-specific antibodies ${ }^{1}$
}

\author{
Carlos Mazur² ${ }^{*}$, Jenner K.P. Reis ${ }^{3}$, Romulo C. Leite ${ }^{3}$, Maria das Graças M. Danelli², \\ Mitika K. Hagiwara ${ }^{4}$, Ana Carolina M.A. de Góes ${ }^{5}$ and Marcos A. Medeiros ${ }^{5}$
}

\begin{abstract}
Mazur C., Reis J.K.P., Leite R.C., Danelli M.G.M., Hagiwara M.K. \& Medeiros M.A. 2010. Evaluation of a recombinant p24 antigen for the detection of Feline Immunodeficiency Virus-specific antibodies. Pesquisa Veterinária Brasileira 30(10):877880. Laboratório de Viroses Veterinárias, Universidade Federal Rural do Rio de Janeiro, Seropédica, RJ 23890-000, Brazil. E-mail: mazur@ufrri.br

Feline Immunodeficiency Virus is a worldwide infection and is considered a significant pathogen. The diagnosis of FIV infections is mainly based on commercially available rapid tests that are highly expensive in Brazil, hence it is rarely performed in the country. Furthermore, lentiviruses grow slowly and poorly in tissue cultures, making the production of viral antigen by classic means and thus the establishment of FIV immunodiagnosis impracticable. In order to deal with this, recombinant DNA techniques were adopted to produce the protein $\mathrm{p} 24$, a viral capsid antigen. The protein's reactivity evaluation analyzed by Western blot indicated that this recombinant antigen can be a useful tool for the immunodiagnostic of FIV infections.
\end{abstract}

INDEX TERMS: FIV, feline immunodeficiency virus, cats.

RESUMO.-[Avaliação do antígeno recombinante p24 para a detecção de anticorpos específicos do Vírus da Imunodeficiência Felina.] O vírus da imunodeficiência felina tem distribuição mundial e é considerado um patógeno significativo. No Brasil, a prática diagnóstica é baseada principalmente em teste rápidos, importados e de custo elevado, disponíveis comercialmente. Devido ao seu custo proibitivo em nosso país, o diagnóstico da infecção pelo FIV é raramente realizado. Ademais, os lentivírus se multiplicam lenta e pobremente em cultura de células, o que torna a produção de antígeno por meios clássicos e o estabelecimento do imunodiagnóstico impraticável. Com o objetivo de lidar com

\footnotetext{
${ }^{1}$ Received on November 11, 2009.

Accepted for publication on July 2, 2010.

${ }^{2}$ Laboratório de Viroses Veterinárias, Universidade Federal Rural do Rio de Janeiro (UFRRJ), BR 465 Km 7, Seropédica, RJ 23890-000, Brazil. * Corresponding author: mazur@ufrrj.br

${ }^{3}$ Laboratório de Retroviroses, Universidade Federal de Minas Gerais, Av. Antonio Carlos 6627, Belo Horizonte, MG 31270-901, Brazil.

${ }^{4}$ Faculdade de Medicina Veterinária e Zootecnia, Universidade de São Paulo (USP), Av. Prof. Dr. Orlando Marques de Paiva 87, São Paulo, SP 05508-270, Brazil.

${ }^{5}$ Laboratório de Tecnologia Recombinante, Vice-Diretoria de Desenvolvimento Tecnológico, Bio-Manguinhos, Fundação Oswaldo Cruz, Av. Brasil 4365, Rio de Janeiro, RJ 21040-360, Brazil
}

esta questão, técnicas de DNA recombinante foram utilizadas para produção de um antígeno do capsídeo viral, a proteína p24. A avaliação da reatividade realizada por Western blot indicou que este antígeno recombinante pode ser útil para o imunodiagnóstico de infecções pelo FIV.

TERMOS DE INDEXAÇÃO: FIV, vírus da imunodeficiência felina, gatos.

\section{INTRODUCTION}

Feline Immunodeficiency Virus (FIV) is a lentivirus that causes a chronic and progressive immunodeficiency and is considered one of the main pathogens of domestic felines. Infected cats show a progressive depletion of CD4+ Tlymphocytes and immunological deficits which, after a long asymptomatic period, may lead to severe opportunistic infections followed by death, characterizing the clinical phase known as Feline Acquired Immunodeficiency Syndrome (FAIDS). Due to the similarity to HIV, FIV-infected cats have been used as experimental models for HIV/AIDS (De Rozieres et al. 2004).

FIV is structured like other lentiviruses. Virions measure 80-100 $\mathrm{nm}$ in diameter and consist of an envelope, a nucleocapsid, a nucleoid and a matrix protein. Surface projections of $8 \mathrm{~nm}$ length are densely dispersed, small, 
inconspicuous spikes that cover evenly the surface. Each virion also contains two copies of the positive-stranded, polyadenylated RNA genome of about 9400 base pairs. The viral genome is divided in three genes, gag, pol and env that codify internal structural proteins, reverse transcriptase and other enzymes and envelope proteins, respectively. There are other several accessory genes (Olmsted et al. 1989, Bendinelli et al. 1995).

Naturally, the control of the disease is linked to the diagnosis of FIV infections, which relies mainly on the detection of specific antibodies which are considered indicators of the persistent infection. Most available FIV diagnostic tests detect serum, plasma, or whole blood antibodies to FIV. The American Association of Feline Practitioners recommends the use of antibody assays to determine the FIV status of all cats, regardless of age or health status, even with an increase of the vaccination practice (Levy et al. 2008).

An ELISA of immobilized labeled antigens that bind to antibodies is the only available FIV test for commercial or in-practice laboratories in North America and other countries, including Brazil. These tests come in kit format for inpractice use, or in a microwell format for laboratory use. This ELISA is based on detection of antibodies against the viral nucleocapsid protein p24 and a positive or negative result depends on a chromogenic reaction relative to a positive control (O'Connor et al. 1989, Mermer et al. 1992). The p24 is the major nucleocapsid protein encoded by the gag gene. Antibody detection against p24 is commonly used in FIV infection diagnosis due to its high conservation and antigenic characteristics (Calzolari et al. 1995, Mermer et al. 1992, Reid et al. 1992). Western blot is also available and is often recommended for confirmatory testing of ELISA positive samples (Barr 1996, Levy et al. 2008).

Nevertheless, routine and research diagnosis for FIV infections still remain problematic in some parts of the world such as Brazil. Despite its large worldwide diffusion and application, the ELISA based rapid tests usage still depends on imported kits with highly restrictive costs in Brazil. Moreover, any immunodiagnostic technique depends on the antigen source and in the case of lentiviruses on viral cultivation in cell cultures, which is expensive and timeconsuming. Perhaps, these factors are the greatest obstacles for the availability of FIV diagnosis in our country

The production of viral proteins by recombinant bacteria or other biological systems has been used for different purposes as an alternative technology to classic methods of protein purification from cultivated virus. Such alternatives are of special interest for viruses that are hardly grown in cell cultures such as lentiviruses. Basically, the desired coding region is ligated in a DNA vehicle as a bacterial plasmid and this construct is inserted in a appropriate biological system to express the recombinant protein, like bacteria. Cultures of recombinant bacteria represent a practical source of the heterologous protein.

With the aim to contribute to FIV diagnosis in Brazil, a recombinant antigen produced by Escherichia coli was developed and its reactivity against sera samples of naturally infected and non-infected cats was evaluated by Western blot (WB), the gold standard test for the diagnosis of FIV and several virus infections.

\section{MATERIALS AND METHODS}

Cloning procedures. A DNA sample obtained from the peripheral blood mononuclear cells (PBMC) of a naturally FIVinfected cat was used successfully in order to amplify the p24 coding region by the PCR. The primer's design was based on the complete FIV B genomic sequence (Genbank/nucleotide database accession number M59418) and the characteristics of the chosen expression vector (pET100/D-TOPO ${ }^{\circledR}$, Invitrogen) (5'-CACCATGCCTATTCAAACAGTAAATGGAG-3', forward and 5'-CAAGAGTTGCATTTTATATCCTGGTGAGCC-3', reverse). The obtained amplicon was inserted in the plasmid expression vector following the manufacturer's recommendations. The correct insertion of the p24 coding region in the recombinant plasmid was confirmed by nucleotide sequencing.

Recombinant protein production. After the transformation of the recombinant plasmid by electroporation, the recombinant protein p24 ( $r$-p24) was over expressed in the selected recombinant bacterial clone induced with 1M IPTG (isopropylD-thiogalactopyranoside) in a shaker incubator at $37^{\circ} \mathrm{C}$ for 4 hours. The purification based on the poly-histidine tail added to the recombinant protein was performed by immobilized metal affinity in nickel-charged resin (IMAC). The purified r-p24 was characterized by polyacrylamide gel electrophoresis (SDSPAGE) that showed a protein of approximately $30 \mathrm{kDa}$ and by WB with anti-histidine monoclonal antibodies.

Western blot assay. WB assays were conducted on a nitrocellulose membrane with about $1.8 \mu \mathrm{g} \mathrm{r}-\mathrm{p} 24$ protein $/ \mathrm{cm}$. For the evaluation of the r-p24 reactivity, 30 seronegative and

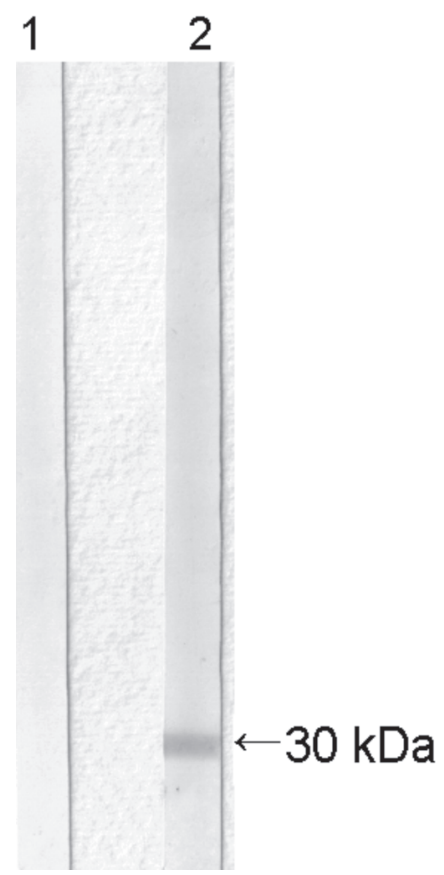

Fig.1. Western blot performed with the r-p24. The strips contain $500 \mathrm{ng}$ of the purified r-p24 (30 kDa) incubated with a negative (1) and positive (2) control serum diluted at 1:50. 
30 seropositive cat serum samples, tested previously by PCR for gag gene and ELISA were used. Basically, this assay was carried out using cat serum samples diluted 1/50 in milk TBS-T (4\% non-fat milk in Tris-tween buffered saline) and horseradish peroxidase-conjugated anti-cat rabbit immunoglobulin (Fig.1).

Statistical analysis. The chi-square test was chosen to evaluate the agreement between the WB versus PCR and ELISA results. The number of control sera samples, 30 positive e 30 negative, was adopted based on chi-square analysis needs.

\section{RESULTS}

The WB assays indicated an agreement of $100 \%$ with the previously performed PCR and ELISA tests, what means that all the 30 positive sera reacted with the r-p24 and that unspecific reactions were not observed in any of the 30 negative sera samples. This result made the chi-square analysis dispensable.

\section{DISCUSSION}

Pedersen et al. (1987) described the isolation of a Tlymphotropic virus with the characteristics of a lentivirus from pet cats in Davis, California. Since then, it was evident that the virus is of substantial veterinary importance. In addition, the FIV infection exposes felines to opportunistic and pathogenic infectious agents, including some zoonotic ones such as toxoplasmas, bartonellas and even possibly, avian pandemic influenza virus (H5N1) (Lappin et al. 1992, Ueno et al. 1996).

FIV infections in cats can be diagnosed by different techniques: based on virus isolation from a peripheral blood lymphocyte culture, demonstration of specific antibodies or molecularly, using the PCR. Virus isolation is technically demanding, expensive, and takes several weeks, hence it hardly can be considered for routine diagnose purposes.

PCR is frequently used to detect, quantify, and assess genetic variations of infectious agents but FIV is difficult to detect by PCR, since gene sequences differ by as much as $20 \%$ among field isolates (Bachmann et al. 1997). Moreover, the amount of virus in blood is low during the clinically silent phase of infection, when most testing is performed (Pedersen et al. 1989). These aspects bring the use of nested PCR approaches, which increase possibilities for false positive results.

FIV antibodies can be detected by the immunofluorescence assay using FIV-infected lymphocytes, ELISA, Western blot and radioimmunoprecipitation assays. Anyway, with the exception of PCR, these techniques depend on the antigen production. Considering the difficulties in obtaining lentivirus antigens from cell cultures, recombinant DNA technology is a simple, economic and available system to produce viral antigens.

FIV diagnostic techniques can be mostly found in the ELISA format, microwell plates and lateral flow systems (rapid tests) that are commercially available. Rapid tests are the most frequently used at veterinary clinics and animal shelters around the world, due to its simplicity and low time consumption (Crawford \& Levy 2007). However, even considering these advantages, the actual cost of these tests showed to be impeditive in countries where it is imported. The microwell ELISA used in veterinary laboratories has been described as having high sensitivity and specificity (Barr et al. 1991). False negative results are rare and mostly due to acute infection prior to the generation of specific antibodies. False positive results have been attributed to poor technique and nonspecific reactivity against tissue culture components following vaccination. Based on these test characteristics, it was recommended that a positive in-practice ELISA in a healthy cat should be confirmed with a Western blot (Barr 1996).

There is a great veterinary interest in a large scale FIV epidemiologic survey in Brazil but the high costs of the rapid test and the difficulty to obtain the viral antigen by classical ways to establish immunodiagnostic techniques may explain the availability of just a few epidemiologic studies found in Brazil and its low numbers of surveyed animals (Teixeira et al. 2007, Caxito 2003, Hagiwara et al. 1987, Laral et al. 2008, Souza et al. 2002). The obtained recombinant bacteria represent a good source for viral antigen production in order to establish alternative diagnosis methods.

\section{CONCLUSION}

The results of the WB assays show that r-p24 can be suitable for the detection of FIV antibodies. The simple and inexpensive production of the r-p24 favors the establishment of FIV immunodiagnostic techniques for epidemiologic and clinical applications of this important animal disease.

Acknowledgments.- To Dr. Zélia Inês Portela Lobato for the excellent technical assistance, to CNPq for supporting Dr. Carlos Mazur with a fellowship and to FAPERJ for financial aid.

\section{REFERENCES}

Bachmann M.H., Mathiason-Dubar C. \& Learn G.H. 1997. Genetic diversity of feline immunodeficiency virus: Dual infection, recombination, and distinct evolutionary rates among envelope sequence clades. J. Virol. 71:4241-4253.

Barr M.C. 1996. FIV, FeLV and FIPV: Interpretation and misinterpretation of serological test results. Semin Vet. Med. Surg. (Small Anim)11:144-153.

Barr M.C., Pough M.B., Jacobson R.H. \& Scott F.W. 1991. Comparison and interpretation of diagnostic tests for feline immunodeficiency virus infection. J. Am. Vet. Med. Assoc. 199:1377-1381.

Bendinelli M., Pistello M., Lombardi S., Poli A., Garzelli C., Matteucci D., Ceccherini-Nelli L., Malvaldi G. \& Tozzini F. 1995. Feline immunodeficiency virus: An interesting model for AIDS studies and an important cat pathogen. Clin. Microbiol. Rev. 8(1):87-112.

Calzolari M., Young E., Cox D., Davis D. \& Lutz H. 1995. Serological diagnosis of feline immunodeficiency virus infection using recombinant transmembrane glycoprotein. Vet. Immunol. Immunopathol. 46:83-92.

Caxito F.A. 2003. Detecção e subtipagem do vírus da imunodeficiência felina em Minas Gerais. Dissertação de Mestrado, Instituto de Ciências Biológicas, Universidade Federal de Minas Gerais, Belo Horizonte, MG. 90p. 
Crawford P.C. \& Levy J.K. 2007. New challenges for the diagnosis of feline immunodeficiency virus infection. Vet. Clin. North Am., Small. Anim. Pract. 37(2):335-50.

De Rozieres S., Mathiason C.K., Rolston M.R., Chatterji U., Hoover E.A. \& Elder J.H. 2004. Characterization of a highly pathogenic molecular clone of feline immunodeficiency virus clade C. J. Virol. 78(17):8971-8982.

Hagiwara M.K., Reche A. Jr \& Lucas S.R.R. 1987. Estudo clínico da infecção de felinos pelo vírus da leucemia felina em São Paulo. Rev. Bras. Ciênc. Vet. 4(1):35-38.

Lappin M.R., Gasper P.W., Rose B.J. \& Powell C.C. 1992. Effect of primary phase feline immunodeficiency virus infection on cats with chronic toxoplasmosis. Vet. Immunol. Immunopathol. 35(1/2):121131.

Laral V.M., Taniwaki S.A. \& Araújo Júnior J.P. 2008. Ocorrência da infecção pelo vírus da imunodeficiência felina em gatos. Ciência Rural 38(8):2245-2249.

Levy J., Crawford C., Hartmann K., Hofmann-Lehmann R., Little S., Sundahl E. \& Thayer V. 2008. American Association of Feline Practitioners' Feline Retrovirus Management Guidelines. J. Feline Med. Surg. 10(3):300-316.

Mermer B., Hillman P., Harris R., Krogmann T., Palin Q.W. \& Andersen P.A. 1992. Recombinant-based feline immunodeficiency virus antibody enzyme-linked immunosorbent assay. Veterinary Immunology and Immunopathology 35(1/2):133-141.

Olmsted R.A., Hirsch V.M., Purcell R.H., Johnson P.R. 1989. Nucleotide sequence analysis of feline immunodeficiency virus: Genome organization and relationship to other lentiviruses. Proc. Natl Acad. Sci. USA 86(20):8088-8092.

O'Connor Jr T.P., Tanguay S. \& Steinman R. 1989. Development and evaluation of immunoassay for detection of antibodies to the feline Tlymphotropic lentivirus (feline immunodeficiency virus). J. Clin. Microbiol. 27:474-479.

Pedersen N.C., Ho E.W., Brown M.L. \& Yamamoto J.K. 1987. Isolation of a T-I anphotropic virus from domestic cats with an immunodeficiencylike syndrome. Science 235:790-793.

Pedersen N.C., Yamamoto J.K., Ishida T. \& Hansen H. 1989. Feline immunodeficiency virus infection. Vet. Immunol. Immunopathol. 21:111-129.

Reid D.R.W., Bam M.C. \& Stori F.W. 1992. Retrospective serological survey for the presence of feline immunodeficiency virus antibody: a comparison of ELISA and IFA techniques. Cornell Veterinary 82:359-369.

Souza H.J.M., Teixeira C.H.R. \& Graça R.F.S. 2002. Estudo epidemiológico de infecções pelo vírus da leucemia e/ou imunodeficiência felina, em gatos domésticos do município do Rio de Janeiro. Clín. Vet. 36(1/2):14-21.

Teixeira B.M., Rajão D.S., Haddad J.P.A., Leite R.C. \& Reis J.K.P. 2007. Ocorrência do vírus da imunodeficiência felina e do vírus da leucemia felina em gatos domésticos mantidos em abrigos no município de Belo Horizonte. Arq. Bras. Med. Vet. Zootec. 59(4):939-942.

Ueno H., Hohdatsu T., Muramatsu Y., Koyama H. \& Morita C. 1996. Does coinfection of Bartonella henselae and FIV induce clinical disorders in cats? Microbiol. Immunol. 40(9):617-620. 